Article

\title{
Sesquiterpene Lactones from Calea pinnatifida: Absolute Configuration and Structural Requirements for Antitumor Activity
}

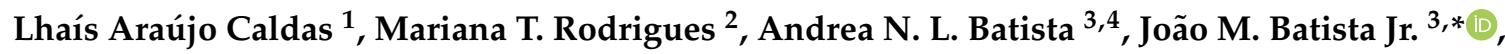 \\ João H. G. Lago ${ }^{5}{ }^{(}$, Marcelo J. P. Ferreira ${ }^{6}{ }^{(}$, Ileana G. S. Rubio ${ }^{1,2}$ and Patricia Sartorelli ${ }^{1, *(\mathbb{C}}$ \\ 1 Instituto de Ciências Ambientais, Químicas e Farmacêuticas, Universidade Federal de São Paulo, \\ 09972-270 Diadema, SP, Brazil; lhais_araujo@hotmail.com (L.A.C.); ilerubio@gmail.com (I.G.S.R.) \\ 2 Programa de Pós-Graduação em Biologia Estrutural e Funcional, Universidade Federal de São Paulo, \\ 04021-001 São Paulo, SP, Brazil; mariana.rodr@outlook.com \\ 3 Instituto de Ciência e Tecnologia, Universidade Federal de São Paulo, São José dos Campos, \\ 12231-280 São José dos Campos, SP, Brazil; andrluca@gmail.com \\ 4 Insitituto de Química, Universidade Federal Fluminense, 24020-141 Niterói, RJ, Brazil \\ 5 Centro de Ciências Naturais e Humanas, Universidade Federal do ABC, 09210-180 Santo André, SP, Brazil; \\ joaohglago@gmail.com \\ 6 Departamento de Botânica, Instituto de Biociências, Universidade de São Paulo, \\ 05508-090 São Paulo, SP, Brazil; marcelopena@ib.usp.br \\ * Correspondence: batista.junior@unifesp.br (J.M.B.J.); psartorelli@unifesp.br (P.S.); \\ Tel.: +55-11-4044-0500 (P.S.)
}

Academic Editors: Bartosz Tylkowski, Anna Bajek and Krzysztof Roszkowski Received: 30 March 2020; Accepted: 22 April 2020; Published: 30 June 2020

check for updates

\begin{abstract}
This work describes the chromatographic fractionation of the aerial parts of Calea pinnatifida and the structural characterization and determination of the absolute configuration of the isolated compounds as well as their antitumor potential. The HPLC fractionation of the $\mathrm{CH}_{2} \mathrm{Cl}_{2}$ phase of the $\mathrm{MeOH}$ extract from the leaves of $C$. pinnatifida led to the isolation of two related sesquiterpene lactones (STLs): calein C (1) and calealactone B (2). Additionally, during the purification process, a derivative of calein $\mathrm{C}$ (3) was formed as a product of the Michael addition of $\mathrm{MeOH}$. The structures of Compounds 1-3 were established based on spectroscopic and spectrometric data, while the absolute stereochemistry was established by vibrational circular dichroism. In order to evaluate the effect of the conjugated double bonds on the cytotoxic activity of STLs, Compounds 1-3 were tested against anaplastic (KTC-2) and papillary (TPC-1) thyroid carcinoma cells. Calein C was the most active of the STLs, and displayed activity against both KTC-2 and TPC-1. On the other hand, the calein C derivative (3) was the least cytotoxic of all the compounds tested. These results are promising and suggest the importance of studying sesquiterpene lactones isolated from $C$. pinnatifida in terms of antitumor activity, especially considering the effects of $\alpha, \beta$-unsaturated carbonyl systems.
\end{abstract}

Keywords: Calea pinnatifida; sesquiterpene lactones; vibrational circular dichroism (VCD); $\alpha, \beta$-unsaturated carbonyl systems; thyroid carcinoma

\section{Introduction}

Calea pinnatifida (R. Br) Less. (Asteraceae), popularly known as aruca, cipó cruz or quebra-tudo, occurs in Brazil, mainly in the "cerrado" biome [1]. This species is used in folk medicine as infusions to treat stomachaches, giardiasis, amoebiasis and gastric disorders in general [2]. According to the literature, phytochemical studies on the plant have revealed sesquiterpene lactones, fatty esters, steroids and a polyacetylene as the main components [2]. 
Sesquiterpene lactones (STLs) constitute a large group of secondary metabolites found in Asteraceae $[3,4]$. The presence of $\alpha, \beta$-unsaturated carbonyl systems in STLs has been described as an important structural feature responsible for bioactivity, since they are capable of acting as Michael acceptors when in contact with biological nucleophiles [5,6]. Furthermore, Michael acceptor compounds are considered important alkylating agents, capable of supporting alkylation reactions through adequate nucleophiles [7].

According to the literature [3], germacranolides appear as one of the most frequent types of STL found in Calea, with more than 40 isolated compounds from C. pinnatifida, C. ternifolia, C. urticifolia and C. zacatechichi [8-13].

Despite the fact that sesquiterpene lactones from Calea have been isolated since the 1970s, important structural information about many STLs, such as their absolute configuration, is still unclear. This is due especially to the large number of possible substituents present in STLs, as well as the lack of specific techniques available in the past for solution-state assignments. Many of the experiments carried out on these molecules were based on X-ray crystallography and degradation reactions, as in the case of neurolenin B, a sesquiterpene lactone that had its relative configuration assigned based on X-ray crystallographic data [9]. Nowadays, bidimensional NMR experiments, combined with vibrational circular dichroism (VCD) measurements and calculations, represent powerful complementary tools to unambiguously define both the relative and absolute configurations of a given molecule directly in solution $[14,15]$.

In terms of biological potential, literature data suggest that STLs might be responsible for the cytotoxic potential of many species, such as C. pinnatifida [16-18] and C. urticifolia [19,20]. Regarding antitumor activity, our research group showed that calein C, an STL isolated from C. pinnatifida, inhibits mitotic progression and induces apoptosis in MCF-7 cell lines by the inhibition of cell cycle progression at the M-phase [18]. Furthermore, analogues of calein C, such as arucanolide, displayed cytotoxicity against melanoma and HL60 cells $[17,21]$.

Over the last years, the development of antineoplastic drugs based on natural products has been mainly due to combinatory chemistry, advanced spectroscopic and spectrometric instruments, and molecular networking [22,23]. However, many cancer tumors are resistant to some antineoplastic drugs administrated, not only the ones obtained from natural sources, but also the most common drugs used, such as cisplatin [24]. This scenario highlights the urgent need for prospecting new drugs.

Thyroid carcinoma is the fifth most common type of cancer among women worldwide [25]. The most common forms of thyroid cancer originate from thyroid follicular cells and can be divided into three major pathological forms: differentiated thyroid cancer (papillary thyroid carcinoma-PTC and follicular thyroid carcinoma-FTC) and undifferentiated thyroid cancer (anaplastic thyroid carcinoma-ATC).

According to literature data, natural products and plant extracts have demonstrated cytotoxic potential against thyroid carcinomas. For example, Pulsatilla koreana, a plant used in traditional Chinese and Korean medicines as an anti-inflammatory agent, showed cytotoxicity against ATC cell lines and caused a reduction in cell growth, inducing apoptosis [26-28].

Based on these issues, and also on the expressive bioactivity of related sesquiterpene lactones, this work aims to evaluate the cytotoxic potential of STLs isolated from C. pinnatifida (calein C, calealactone $B$ and a derivative obtained from calein $C$ ) against thyroid tumor cell lines, exploring the differences observed between structures in terms of the presence of $\alpha, \beta$-unsaturated carbonyl systems. Additionally the absolute configurations of natural products $\mathbf{1}$ and $\mathbf{2}$ were confirmed by VCD spectroscopy. 


\section{Results}

\subsection{Structural Elucidation of Compounds 1-3}

The chromatographic procedures carried out allowed the isolation of three compounds: calein C (1), calealactone B (2) and a calein C derivative (3), a product of a Michael addition reaction with methanol (Figure 1).<smiles>C=C(C)C(=O)O[C@H]1[C@@H]2C(=C)C(=O)O[C@H]2C[C@@]2(C)C=CC(=O)[C@@]1(C)[C@H]2OC(C)=O</smiles>

1

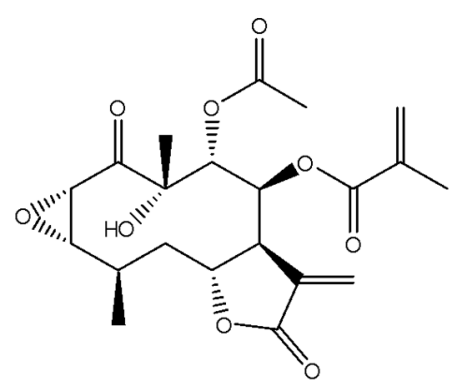

2

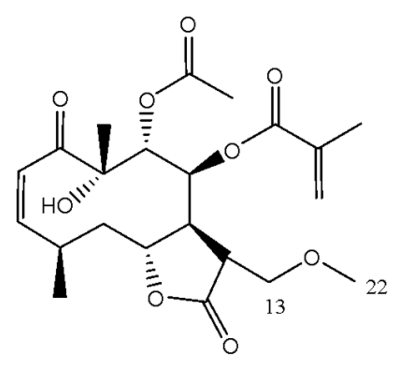

3

Figure 1. Structures of calein C (1), calealactone B (2) and the derivative of calein C (3).

Compound 1 was obtained as a colourless crystal, mp. $170{ }^{\circ} \mathrm{C}$. ESI-HRMS (positive mode) data displayed a pseudo-molecular ion peak at $m / z 429.1542[\mathrm{M}+\mathrm{Na}]^{+}$corresponding to the molecular formula $\mathrm{C}_{21} \mathrm{H}_{26} \mathrm{O}_{8} \mathrm{Na}$ (calculated $\mathrm{m} / z$ : 429.1553). All signals in the ${ }^{1} \mathrm{H}$ - and ${ }^{13} \mathrm{C}-\mathrm{NMR}$ spectra were attributed by the analysis of the ${ }^{1} \mathrm{H}-{ }^{1} \mathrm{H}$ COSY, HMQC, HMBC and NOESY (Figure 2) spectra recorded in benzene- $d_{6}$.

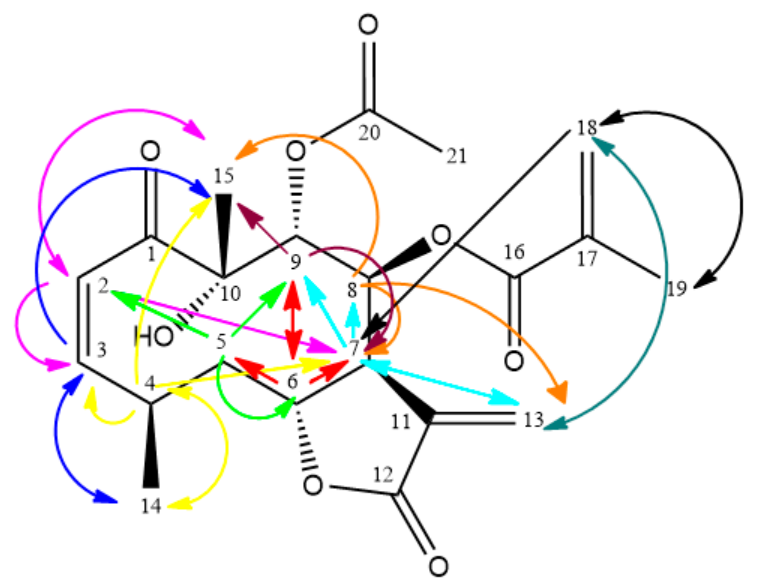

Figure 2. NMR NOESY correlations of $\mathbf{1}$.

Once the relative configuration of Compound 1 was unambiguously assigned by NOESY analysis, vibrational circular dichroism (VCD) experiments and calculations were used to determine its absolute stereochemistry for the first time in the literature. VCD associated with density functional theory (DFT) calculations has been demonstrated as a powerful probe for chirality in natural products [14,15].

The very good agreement between the experimental VCD spectra obtained in $\mathrm{CDCl}_{3}$ and simulated data at the B3PW91/6-311G(d,p) level led to the assignment of the $4 R, 6 R, 7 S, 8 S, 9 R, 10 R$ configuration to Compound 1 (Figure 3 ). The most representative vibrational modes used in this assignment were those at (-)-1025 cm $\mathrm{cm}^{-1}$ (C-O stretch of C-6, C-8, C-9 and C-10), (-)-1125 and (-)-1145 cm $\mathrm{cm}^{-1}$ (C-H bending of whole molecular framework), and (-)-1345 and (-)-1365 $\mathrm{cm}^{-1}$ (out-of-plane and in-plane $\mathrm{C}-\mathrm{H}$ bending of C-6, C-7, C-8 and C-9). 


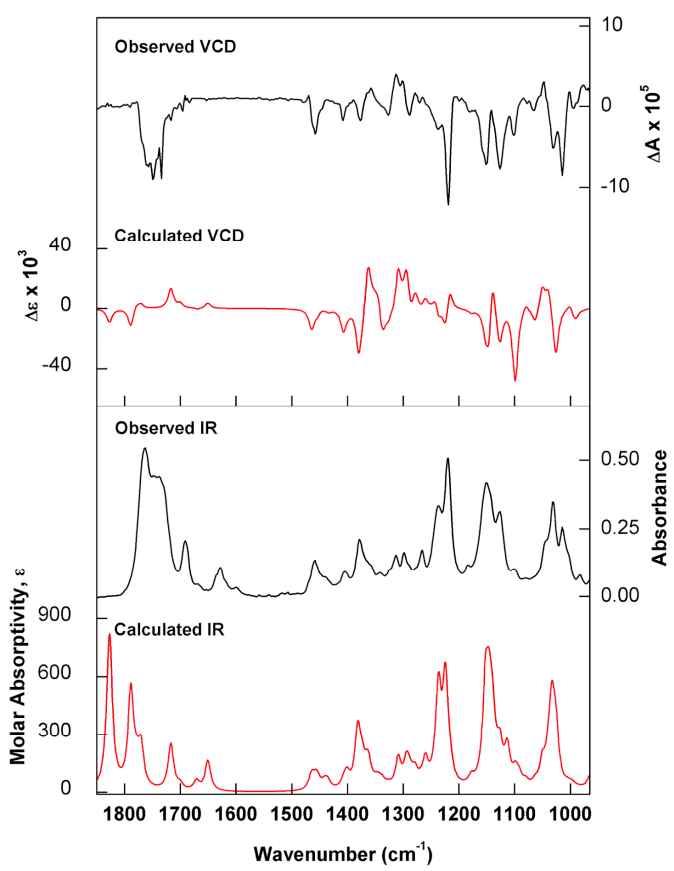

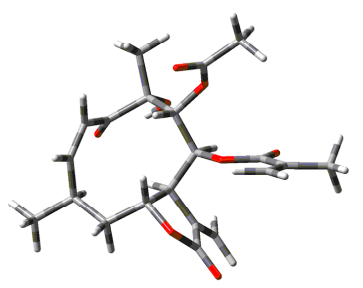

Conf 1. $0.0 \mathrm{kcal} \mathrm{mol}^{-1}(55 \%)$

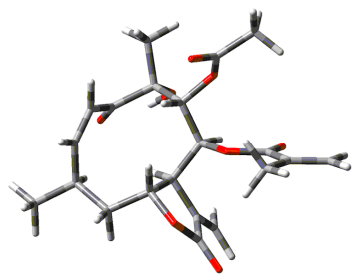

Conf 2. $+0.13 \mathrm{kcal} \mathrm{mol}^{-1}(45 \%)$

Figure 3. (Left) Comparison of experimental IR and vibrational circular dichroism (VCD) spectra of (-)-1 recorded in $\mathrm{CDCl}_{3}$ (black trace) with the calculated [B3PW91/6-311G(d,p)] IR and VCD spectra for the Boltzmann average of the two lowest-energy conformers identified for $(4 R, 6 R, 7 S, 8 S, 9 R, 10 R)-\mathbf{1}$ (red trace). (Right) Optimised structures, relative energies and Boltzmann populations of the lowest-energy conformers identified for $(4 R, 6 R, 7 S, 8 S, 9 R, 10 R)-\mathbf{1}$.

Compound 1, identified as calein C, was previously isolated from C. urticifolia [8] and C. zacatechichi [9]. Our group has also studied this compound previously in order to determine the correct relative position of the acetate and methacrylate groups, by means of HSQC and HMBC NMR in benzene- $d_{6}$ (Table 1) $[18,29]$, which were assigned to C-9 and C-8, respectively.

NMR and MS data analyses of calealactone B (2) demonstrated that this STL is an analogue of calein $\mathrm{C}$, containing an epoxide ring at $\mathrm{C}-2$ and $\mathrm{C}-3$. The ${ }^{1} \mathrm{H}-\mathrm{NMR}$ spectrum was similar to that of 1, but it was possible to observe slight differences in $\mathrm{H}-2\left(\delta_{\mathrm{H}} 4.23 d\right)$ and $\mathrm{H}-3\left(\delta_{\mathrm{H}} 3.34 d d\right)$ patterns that correspond to oxirane hydrogens. The relative configuration of the stereogenic centers $\mathrm{C}-2, \mathrm{C}-3$, C-4, C-6, C-7, C-8, C-9 and C-10 in the structure of Compound 2 was established using the NOESY spectrum, and its absolute configuration was also unambiguously determined by means of VCD and DFT calculations. Comparisons of experimental and calculated spectra allowed the assignment of (-)-2 as $2 S, 3 S, 4 R, 6 R, 7 S, 8 S, 9 R, 10 R$ (Figure 4).

As expected, the VCD spectra obtained for (-)-2 were very similar to those of (-)-1, as they share most of the structural and stereochemical features. The negative bands at around 1025, 1090 and $1140 \mathrm{~cm}^{-1}$, however, contain significant contributions from the C-H bending (out-of-plane) of C-2 and $\mathrm{C}-3$, comprising the oxirane ring. The positive features between 1230 and $1260 \mathrm{~cm}^{-1}$ arise mainly from oxirane vibrations such as $\mathrm{C}-\mathrm{O}$ stretch coupled to $\mathrm{C}-\mathrm{H}$ bendings. Finally, the region between 1350 and $1400 \mathrm{~cm}^{-1}$ is influenced, among other vibrational modes, by in-plane C-H bendings of C-2 and C-3 coupled to $C-C$ stretches to neighbouring carbons. Calealactone $B$ was previously isolated from the genus Calea [11]. However, this compound has not been described in C. pinnatifida. 
Table 1. ${ }^{1} \mathrm{H}-(300 \mathrm{MHz})$ and ${ }^{13} \mathrm{C}-\mathrm{NMR}(75 \mathrm{MHz})$ spectral data for Compounds $1-3$.

\begin{tabular}{|c|c|c|c|c|c|c|c|c|}
\hline & & $1^{a}$ & & & $2^{b}$ & & $3^{b}$ & \\
\hline No & ${ }^{1} \mathbf{H}$ & ${ }^{13} \mathrm{C}$ & NOESY ${ }^{1} \mathbf{H}$ & & ${ }^{13} \mathrm{C}$ & NOESY & ${ }^{1} \mathbf{H}$ & ${ }^{13} \mathrm{C}$ \\
\hline 1 & - & 204.3 & - & - & 205.9 & - & - & 204.7 \\
\hline 2 & $5.77 d(J 11.7 \mathrm{~Hz})$ & 124.9 & H-15, H-7, H-3 & $4.24 d(J 4.2 \mathrm{~Hz})$ & 62.9 & H-15, H-3, H-9 & $\begin{array}{c}6.55 d \\
(J 12.0 \mathrm{~Hz})\end{array}$ & 125.6 \\
\hline 3 & $4.72 t(J 11.7 \mathrm{~Hz})$ & 147.5 & H-14, H-15, H-4, H-6, H-2, H-5 & $3.33 d d(J 9.3 ; 4.2 \mathrm{~Hz})$ & 55.6 & H-2, H-14 & $\begin{array}{c}6.01 t \\
(J 12.0 \mathrm{~Hz})\end{array}$ & 147.1 \\
\hline 4 & $2.57 m$ & 27.8 & $\begin{array}{c}\text { H-14, H-15 } \\
\text { H-7, H-3 }\end{array}$ & $1.60 \mathrm{sl}$ & 26.0 & $\mathrm{OH}, \mathrm{H}-7$ & $3.11 \mathrm{~m}$ & 28.7 \\
\hline 5 & $0.71 \mathrm{~m} / 0.99 \mathrm{~m}$ & 40.0 & H-9, H-2, H-6 & $1.46 \mathrm{~m} / 1.90 \mathrm{~m}$ & 38.8 & $\mathrm{H}-14, \mathrm{H}-21$ & $1.61 \mathrm{~s} / 1.85 \mathrm{brs}$ & 38.2 \\
\hline 7 & 2.24 brs & 41.3 & $\begin{array}{c}\text { H-6, H-8, H-9, } \\
\text { H-13 }\end{array}$ & 2.36 brs & 40.9 & H-5, H-6, H-8 & $3.08 \mathrm{~m}$ & 40.2 \\
\hline 8 & $5.70 d d(J 9.8 ; 2.0 \mathrm{~Hz})$ & 74.6 & H-7, H-13, H-15 & $\begin{array}{c}5.68 \mathrm{dd} \\
(\mathrm{g} 9.9 ; 1.2 \mathrm{~Hz})\end{array}$ & 71.5 & H-5, H-21, H-7, H-6 & $5.64 m$ & 69.3 \\
\hline 9 & $5.43 d(J 9.8 \mathrm{~Hz})$ & 73.9 & H-6, H-7, H-15 & $5.77 d(J 9.9 \mathrm{~Hz})$ & 73.9 & H-2, H-6, H-15 & $\begin{array}{c}5.60 \mathrm{~d} \\
(J 4.5 \mathrm{~Hz})\end{array}$ & 74.7 \\
\hline 10 & - & 79.1 & - & - & 74.6 & - & - & 79.2 \\
\hline 11 & - & 131.5 & - & - & 134.3 & - & - & 37.5 \\
\hline 12 & - & 168.0 & - & - & 168.3 & - & - & 174.1 \\
\hline 14 & $0.33 d(J 6.3 \mathrm{~Hz})$ & 19.0 & $\mathrm{H}-4, \mathrm{H}-3$ & $1.22 d(J 6.1 \mathrm{~Hz})$ & 18.6 & $\mathrm{H}-3$ & $\begin{array}{c}1.16 \mathrm{~d} \\
(\mathrm{~J} 6.0 \mathrm{~Hz})\end{array}$ & 19.8 \\
\hline 15 & $0.84 s$ & 23.2 & H-2, H-9 & $1.46 s$ & 24.5 & $\mathrm{H}-2$ & $1.32 \mathrm{~s}$ & 23.5 \\
\hline 16 & - & 165.2 & - & - & 165.3 & - & - & 165.4 \\
\hline 17 & - & 135.7 & - & - & 134.8 & - & - & 131.5 \\
\hline 18 & $4.93 s / 5.96 s$ & 125.2 & H-7, H-13, H-19 & $5.57 \mathrm{brs} / 6.04 \mathrm{brs}$ & 127.3 & H-19 & $5.57 \mathrm{~s} / 6.05 \mathrm{~s}$ & 127.5 \\
\hline 19 & $1.58 \mathrm{~s}$ & 17.8 & H-18 & $1.85 \mathrm{~s}$ & 18.1 & $\mathrm{H}-18$ & $1.86 \mathrm{~s}$ & 18.0 \\
\hline 20 & - & 170.0 & - & - & 170.4 & - & - & 170.1 \\
\hline 21 & $1.38 \mathrm{~s}$ & 19.5 & - & $2.05 s$ & 20.3 & H-9, H-19 & $2.02 \mathrm{~s}$ & 20.4 \\
\hline 22 & - & - & - & - & - & - & $3.36 s$ & 59.2 \\
\hline
\end{tabular}

${ }^{\mathrm{a}}$ Benzene $d_{6} ;{ }^{\mathrm{b}} \mathrm{CDCl}_{3}$ 


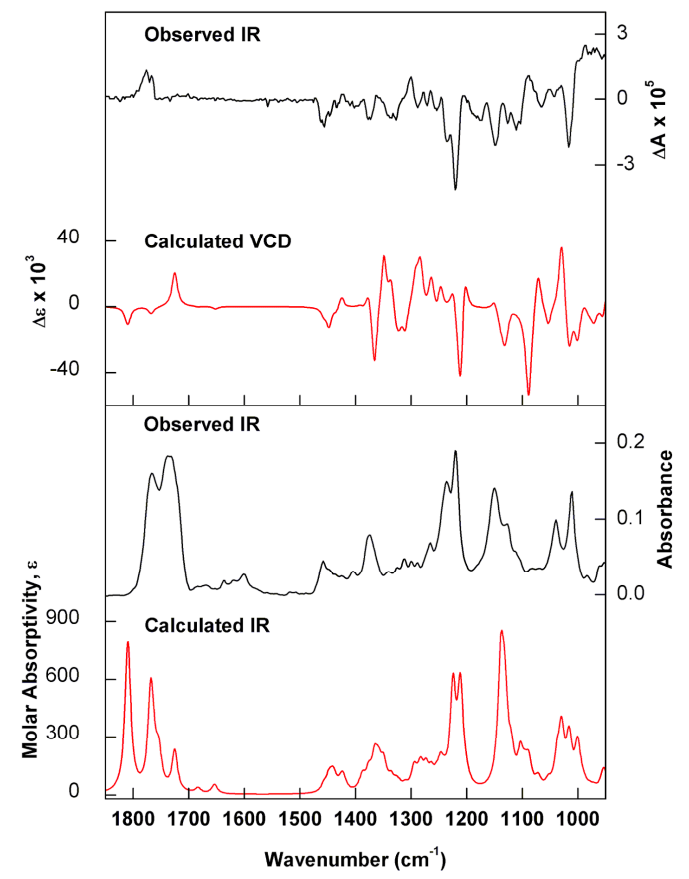

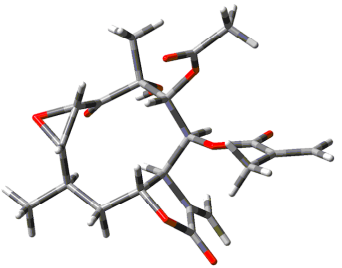

Conf $1.0 .0 \mathrm{kcal} \mathrm{mol}^{-1}(52 \%)$

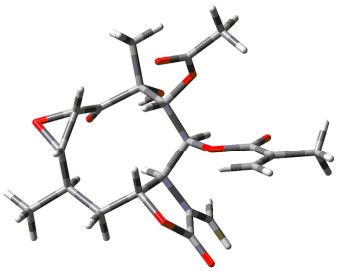

Conf 2. $+0.07 \mathrm{kcal} \mathrm{mol}^{-1}(48 \%)$

Figure 4. (Left) Comparison of the experimental IR and VCD spectra of (-)-2 recorded in $\mathrm{CDCl}_{3}$ (black trace) with the calculated [B3PW91/6-311G(d,p)] IR and VCD spectra for the Boltzmann average of the two lowest-energy conformers identified for $(2 S, 3 S, 4 R, 6 R, 7 S, 8 S, 9 R, 10 R)-2$ (red trace). (Right) Optimised structures, relative energies and Boltzmann populations of the lowest-energy conformers identified for $(2 S, 3 S, 4 R, 6 R, 7 S, 8 S, 9 R, 10 R)-2$.

Compound (3), a calein $\mathrm{C}$ derivative obtained as an artefact by reaction with $\mathrm{MeOH}$ in Michael addition, was also evaluated. The HR-ESI-MS spectrum revealed the $[\mathrm{M}+\mathrm{H}]^{+}$peak at $m / z 439.1980$, corresponding to the molecular formula $\mathrm{C}_{22} \mathrm{H}_{30} \mathrm{O}_{9}$ (calculated for $\mathrm{C}_{22} \mathrm{H}_{31} \mathrm{O}_{9}: m / z 439.1968$ ). According to ${ }^{1} \mathrm{H}$-NMR data (Table 1$)$, it was possible to observe signals at $\delta_{\mathrm{H}} 3.36(s, 3 \mathrm{H})$ that suggested the presence of a methoxy group replacing the exocyclic double bond in the lactone ring. In the ${ }^{13} \mathrm{C}-\mathrm{NMR}$, the presence of the signal $\delta_{C} 66.4$ attributed to $C-13$, which appears shifted upfield compared to that observed for calein $C\left(\delta_{C} 126.3\right)$, indicated the absence of the exocyclic double bond at $C-11 / C-13$ as present in the lactone ring of Compounds $\mathbf{1}$ and 2. Additionally, the ${ }^{13} \mathrm{C}$ data revealed the presence of an extra carbon $\delta_{C} 59.2$, attributed to the methoxyl carbon. According to HMBC spectrum, it was possible to observe a correlation of $\mathrm{H}-13\left(\delta_{\mathrm{H}} 3.70 / 3.35\right)$ with $\mathrm{C}-22\left(\delta_{\mathrm{C}} 59.2\right)$ and $\mathrm{C}-12\left(\delta_{\mathrm{C}} 174.1\right)$, as well as the correlations between $\mathrm{H}-7\left(\delta_{\mathrm{H}} 3.08\right)$ and $\mathrm{C}-13\left(\delta_{\mathrm{C}} 66.4\right)$, confirming the position of the methoxyl group at C-13 (see supplementary data).

In order to define the importance of the conjugated system in the lactone ring to the biological activity, Compound (3) was also investigated in terms of cytotoxicity against anaplastic and papillary thyroid cancer cell lines.

\subsection{Biological Assays}

Cytotoxic assays revealed that KTC-2 and TPC-1 tend to be more sensitive to calein C (1) than to the other substances tested (Table 2). This pattern is also observed in nontumor cells treated with (1) (NIH-3T3). Calealactone B (2) resulted in similar cytotoxic values against the cell lines tested when compared to calein $C$ (1), probably due to their analogous chemical structures. The calein $C$ derivative (3) was shown to be the least cytotoxic of the STLs tested in all cell lines, including fibroblasts.

In general, it is possible to observe that all substances were cytotoxic against all of the cell lines. However, the $\mathrm{IC}_{50}$ data show that calein $\mathrm{C}$ has a slight tendency to be more cytotoxic to the cells, mainly for papillary cells TPC-1 (IC $501.49 \mu \mathrm{M})$. In addition to that, anaplastic cells KTC-2 were also 
affected by the treatment with calein $\mathrm{C}\left(\mathrm{IC}_{50} 1.67 \mu \mathrm{M}\right)$. The literature also reports the cytotoxicity of calein $C$ against the breast cancer cell lines MCF-7, MDA-MB-231 and Hs578T. The data suggest that calein $\mathrm{C}$ is able to reduce cell viability as well as inhibit cell cycle progression, consequently resulting in cell death [18].

Table 2. $\mathrm{IC}_{50}(\mu \mathrm{M})$ determined for anaplastic cancer cells (KTC-2), papillary cancer cells (TPC-1) and murine fibroblasts (NIH-3T3).

\begin{tabular}{cccc}
\hline & KTC-2 & TPC-1 & NIH-3T3 \\
\hline Calein C (1) & 1.67 & 1.49 & 3.06 \\
Calealactone B (2) & 4.69 & 3.54 & 4.40 \\
Calein C derivative (3) & 25.32 & 23.25 & 18.54 \\
Cisplatin & 2.21 & 3.05 & 10.38 \\
\hline
\end{tabular}

$\mathrm{IC}_{50}$ values were calculated using non-linear regression in GraphPad Prism 5.0.

Similarly to what is observed with calein C, calealactone B was also shown to be cytotoxic against both of the cell lines, whereas the $\mathrm{IC}_{50}$ values were slightly higher than those obtained for calein $\mathrm{C}$. This difference might be due to the presence of an epoxide in positions C-2 and C-3 instead of the double bond present in calein $\mathrm{C}$.

On the other hand, the cytotoxic potential of the calein $C$ derivative (3) was the least effective against both cell lines tested, for anaplastic $\left(\mathrm{IC}_{50} 25.3 \mu \mathrm{M}\right)$ and papillary $\left(\mathrm{IC}_{50} 23.6 \mu \mathrm{M}\right)$. It was possible to see that the addition of the methoxy group at C-13, replacing the double bond, drastically changes the biological response.

The potential of a compound to be cytotoxic against anaplastic thyroid carcinoma is an interesting achievement considering that this type of carcinoma is highly aggressive and that no accurate treatment is currently available [30]. According to literature data, the cytotoxic potentials of isolated natural products against ATC are not widely studied. However, Pulsatilla koreana extract, used in traditional Chinese and Korean medicines, was shown to suppress the growth of anaplastic carcinoma in a dose-dependent manner, possibly also acting as an apoptosis inductor [26]. In addition, a flavonoid fraction obtained from Citrus reticulata juice also led to the reduction of ATC cell migration and proliferation in a time-dependent manner, acting in the G2/M phase of the cycle, and consequently promoting cell death [31].

Other phytochemicals, such as resveratrol, a phytoalexin present in several plant species; curcumin, a phenolic compound obtained from the rhizomes of turmeric (Curcuma longa); genistein, an isoflavone naturally found in numerous plants; and epigallocatechin gallate (EGCG), a polyphenolic compound found in green tea, induced a strong and significant reduction of the viability of ATC cell lines [32]. These results reinforce the importance of testing natural products on thyroid cancer cells with the objective of prospecting new drug prototypes.

According to the literature, the cytotoxicity of STLs containing an $\alpha, \beta$ unsaturated carbonyl system was demonstrated to be important when tested against Trypanosoma brucei [27]. Moreover, Padilla-Gonzalez and collaborators [5] described that $\alpha, \beta$ unsaturated carbonyl systems in STLs can participate in Michael addition with biological nucleophiles, showing high cytotoxic potential in biological media. Based on that, we believe that the presence of the $\alpha, \beta$-unsaturated lactone found in Compounds 1 and 2, might be important for the antitumor activity of STLs, since its loss in Compound 3 extinguished this activity.

\section{Materials and Methods}

\subsection{General Experimental Procedures}

${ }^{1} \mathrm{H}$ - and ${ }^{13} \mathrm{C}-\mathrm{NMR}$ spectra of Compounds 1-3 were recorded, respectively, at 300 and $75 \mathrm{MHz}$ in a Bruker Ultrashield 300 Advance III spectrometer. $\mathrm{CDCl}_{3}$ (Aldrich, St. Louis, MO, USA) and benzene- $d_{6}$ 
(Aldrich) were used as solvents and as the internal standards. Silica gel flash (Merck, 230-400 mesh, New Jersey, NJ, USA) and Sephadex LH-20 (Amersham Biosciences, Little Chalfont, UK) were used for column chromatographic separations, while silica gel $60 \mathrm{PF}_{254}$ (Merck) was used for analytical thin-layer chromatography (TLC). HPLC analysis was performed in a Dionex Ultimate 3000 chromatography system (Dionex, Sunnyvale, CA, USA), using a Luna Phenomenex RP-18 column $(3 \mu \mathrm{m}, 150 \times 5 \mathrm{~mm})$ and UV-DAD detector. IR and VCD spectra of Compounds 1 and $\mathbf{2}$ were recorded with a Single-PEM ChiralIR-2X FT-VCD spectrometer (BioTools, Inc., Jupiter, FL, USA) using a resolution of $4 \mathrm{~cm}^{-1}$ and a collection time of $6 \mathrm{~h}$. The optimum retardation of the ZnSe photoelastic modulator (PEM) was set at $1400 \mathrm{~cm}^{-1}$. Minor instrumental baseline offsets were eliminated from the final VCD spectra of $\mathbf{1}$ and 2 by subtracting their VCD data from those obtained for the solvent under identical conditions. The IR and VCD spectra were recorded in a $\mathrm{BaF}_{2}$ cell with a $100 \mu \mathrm{m}$ path length, using $\mathrm{CDCl}_{3}$ as the solvent. The samples were prepared as follows: $5 \mathrm{mg}$ of $\mathbf{1}$ were added to $120 \mu \mathrm{L}$ of $\mathrm{CDCl}_{3}$ and $3 \mathrm{mg}$ of 2 were added to $110 \mu \mathrm{L}$ of $\mathrm{CDCl}_{3}$.

\subsection{Plant Material}

Leaves of Calea pinnatifida (R. Br) Less. (Asteraceae) were collected from the Atlantic Forest area of São Paulo City, SP, Brazil (coordinates 23 53'08.86"S, 46 40'10.45”W), in October 2012. A voucher specimen (C.R. Figueiredo 25) has been deposited in the SPF Herbarium of Botany Department from the Biosciences Institute of University of São Paulo.

\subsection{Extraction and Isolation of Compounds}

Fresh leaves of $C$. pinnatifida (300 g) were dried, ground and then exhaustively extracted using $\mathrm{MeOH}$ at room temperature. After evaporation of the solvent under reduced pressure, the obtained crude extract ( $10 \mathrm{~g}$ ) was resuspended in $\mathrm{MeOH} / \mathrm{H}_{2} \mathrm{O}(2: 1)$ and then partitioned with dichloromethane. The $\mathrm{CH}_{2} \mathrm{Cl}_{2}$ phase (650 mg) was subjected to column chromatography (CC) over Sephadex LH-20 using $\mathrm{MeOH}$ as a mobile phase to give seven fractions (A-G). Fraction B (420 mg) was subjected to CC over silica flash using increasing amounts of $\mathrm{MeOH}$ in $\mathrm{CH}_{2} \mathrm{Cl}_{2}$ as the solvent, to afford three fractions (B1-B3). Part of Fraction B1 (100 mg) was purified over semi-prep RP-18 HPLC, eluted with ACN/H $\mathrm{H}_{2} \mathrm{O}$ (4:6) (flow rate: $\left.3.6 \mathrm{~mL} \mathrm{~min}^{-1}, \lambda: 218 \mathrm{~nm}\right)$, to afford calein $\mathrm{C}(\mathbf{1}, 40.0 \mathrm{mg})$ and calealactone $\mathrm{B}(\mathbf{2}, 9.0 \mathrm{mg})$. In the course of extraction and fractionation, a calein $C$ derivative $(3,2.8 \mathrm{mg} ; 7.0 \%$ of $\mathbf{1})$ was produced and isolated.

\subsection{Cell Lines Culture}

In order to assess the cytotoxic effects of the STLs, two thyroid cancer cell lines-KTC-2 (anaplastic thyroid cell line) and TPC-1 (papillary thyroid cancer cell line), donated by Professor Edna Kimura-and the murine fibroblast nontumor cell line NHT-3T3 were selected. KTC-2 and TPC-1 were maintained in RPMI-1640 (ThermoFisher Scientific, Waltham, MA, USA) supplemented with 5\% and 10\% fetal bovine serum (ThermoFisher Scientific), respectively, and $0.01 \mu \mathrm{g} \mathrm{mL}^{-1}$ of penicillin-streptomycin (ThermoFisher Scientific). NIH-3T3 was maintained in DMEM (ThermoFisher Scientific) supplemented with $10 \%$ fetal bovine serum (ThermoFisher Scientific). All cell lines were cultured at $37{ }^{\circ} \mathrm{C}$ with $5 \% \mathrm{CO}_{2}$.

\subsection{Cell Viability Assay and Determination of $\mathrm{IC}_{50}$ Value}

The cell viability after drug treatments was determined with PrestoBlue Cell Viability Reagent (ThermoFisher Scientific), following the manufacturer's instructions. Briefly, the thyroid cancer cells (KTC2 and TPC1) and the nontumor cell line (NIH-3T3) were seeded into 96-well plates at an initial density of 1000 cells per well and incubated at $37^{\circ} \mathrm{C}$ for $48 \mathrm{~h}$. Cells were treated with three concentrations of calein $C(73.9,36.9$ and $18.5 \mu \mathrm{M})$, calein $C$ derivative $(68.3,34.2$ and $15.9 \mu \mathrm{M})$ and calealactone B $(70.9,35.4$ and $17.7 \mu \mathrm{M})$ for $72 \mathrm{~h}$. A concentration of $10 \mu \mathrm{M}$ of cisplatin was used as the positive control in the KTC2 and TPC1 cell lines for cytotoxicity. After $48 \mathrm{~h}$ of treatment, $10 \mu \mathrm{L}$ 
of PrestoBlue reagent was added to each well and incubated for $1 \mathrm{~h} 30 \mathrm{~min}$. Fluorescence (540 nm excitation/590 nm emission) was measured using a microplate reader, M3 (Molecular Devices, SoftMax Pro 7 Software). Vehicle-treated control cells (DMSO) were used to normalize the relative luminescence units from treated wells, and they were expressed as percentages of viable cells. The concentration to achieve $50 \%$ of cell death $\left(\mathrm{IC}_{50}\right)$ was estimated from the non-linear regression analysis of the dose response curve using Prism 5 (GraphPad Prism 5, version 5.01). Cells were briefly treated with different concentrations of each compound for $72 \mathrm{~h}$ at concentrations ranging from 12.3 to $0.096 \mu \mathrm{M}$ for calein C, 60.3 to $0.532 \mu \mathrm{M}$ for calein C derivative and 17.7 to $0.137 \mu \mathrm{M}$ for calealactone B. After $48 \mathrm{~h}$ treatment, $10 \mu \mathrm{L}$ of PrestoBlue reagent was added to each well and incubated for $1.5 \mathrm{~h}$. Fluorescence was also measured at M3. All experiments were performed in triplicate and data were expressed as the mean \pm SEM.

\subsection{Calculations}

Calculations were performed for the arbitrarily chosen $(4 R, 6 R, 7 S, 8 S, 9 R, 10 R)-\mathbf{1}$ and $(2 S, 3 S, 4 R, 6 R$, $7 S, 8 S, 9 R, 10 R)-2$. Conformational searches were carried out at the molecular mechanics level of theory with the Monte Carlo algorithm, employing the $\mathrm{MM}+$ force field incorporated in the HyperChem 8.0.10 software package. Initially, 34 conformers of $(4 R, 6 R, 7 S, 8 S, 9 R, 10 R)-1$ and 29 conformers of $(2 S, 3 S, 4 R, 6 R, 7 S, 8 S, 9 R, 10 R)-2$ with a relative energy (rel E.) within $10 \mathrm{kcal} \mathrm{mol}^{-1} \mathrm{of}^{-}$ the lowest-energy conformer were selected and further geometry-optimised at the B3LYP/6-31G(d) and B3PW91/6-311G(d,p) levels. The two conformers with rel E. $<4.0 \mathrm{kcal} \mathrm{mol}^{-1}$ for each compound, which corresponded to more than $99 \%$ of the total Boltzmann distributions, were selected for IR and VCD spectral calculations. DFT calculations were carried out at $298 \mathrm{~K}$ in the gas phase using Gaussian 09 software [33]. The IR and VCD spectral simulations were created using dipole and rotational strengths from Gaussian, which were calculated at the same level used during the geometry optimisation steps, and converted into molar absorptivities $\left(\mathrm{M}^{-1} \mathrm{~cm}^{-1}\right)$. Vibrational analysis at the B3LYP/6-31G(d) and B3PW91/6-311G(d,p) levels resulted in no imaginary frequencies, confirming the considered conformers as real minima. Each spectrum was plotted as a sum of Lorentzian bands with half-widths at half-maximum of $6 \mathrm{~cm}^{-1}$. The calculated wavenumbers were multiplied by a scaling factor of 0.975 . The final spectra were generated according to Boltzmann weighting of the lowest-energy conformers identified for $\mathbf{1}$ and $\mathbf{2}$ and plotted using the Origin 8 software.

\section{Conclusions}

From the $\mathrm{MeOH}$ extract of the leaves of Calea pinnatifida, two sesquiterpene lactones (STLs) were isolated: calein C (1) and calealactone B (2), while Compound 3 was obtained as a product of the Michael addition of $\mathrm{MeOH}$ to calein $\mathrm{C}$. The absolute configurations of $\mathbf{1}$ and $\mathbf{2}$ were unambiguously confirmed as $4 R, 6 R, 7 S, 8 S, 9 R, 10 R$ and $2 S, 3 S, 4 R, 6 R, 7 S, 8 S, 9 R, 10 R$, respectively, by means of VCD and DFT calculations. According to the biological data obtained, it was possible to observe that calein C, calealactone B and the calein C derivative were effectively cytotoxic against thyroid cancer cells, both papillary and anaplastic. However, differences in conjugated double bonds among the structures of the STLs were shown to influence their cytotoxic potential. KTC-2 and TPC-1 were shown to be more sensitive to calein $C$ than to the other tested substances. Thus, the obtained results demonstrate how the presence of an $\alpha, \beta$-unsaturated lactone ring might be important for the antitumor activity. To the best of our knowledge, this is the first report of the calein C derivative (3) and the structure-activity relationship among sesquiterpene lactone analogues from $C$. pinnatifida, suggesting the importance of conjugated systems in their biological potential.

Supplementary Materials: The following are available online, Figure S1: ${ }^{1} \mathrm{H}-\mathrm{NMR}$ spectrum of (1), Figure S2: ${ }^{13}$ C-NMR spectrum of (1), Figure S3: HMBC NMR spectrum of (1), Figure S4: NOESY NMR spectrum of (1), Figure S5: ${ }^{1} \mathrm{H}-\mathrm{NMR}$ spectrum of (2), Figure S6: ${ }^{13} \mathrm{C}-\mathrm{NMR}$ spectrum of (2), Figure S7: NOESY NMR spectrum of (2), Figure S8: ${ }^{1} \mathrm{H}-\mathrm{NMR}$ spectrum of (3), Figure S9: ${ }^{13} \mathrm{C}-\mathrm{NMR}$ spectrum of (3). 
Author Contributions: Conceptualization, P.S.; methodology, L.A.C., M.T.R., A.N.L.B.; software, J.M.B.J.; Experimental work, data collection and evaluation, P.S., L.A.C., M.T.R., A.N.L.B.; spectral analysis, P.S., J.H.G.L., M.J.P.F.; Literature search and manuscript preparation, L.A.C., J.M.B.J., I.G.S.R., P.S.; writing—review and editing, J.M.B.J., I.G.S.R., P.S.; project administration, P.S., J.M.B.J.; funding acquisition, P.S., J.M.B.J. All authors have read and agreed to the published version of the manuscript.

Funding: This research was funded by the Fundação de Amparo à Pesquisa do Estado de São Paulo (FAPESP), Grant\# 2020/05741-2, 2016/24985-4, and 2014/25222-9. L.A.C, M.T.R and A.N.L.B. were funded by PhD and Post-Doc scholarships from Coordenação de Aperfeiçoamento de Pessoal de Nível Superior (CAPES Cod. 001, \#88887.313278/2019-00). P.S., J.H.G.L. and M.J.P.F. received a scientific research award from CNPq.

Acknowledgments: The authors thank the resources supplied by the Centre for Scientific Computing (NCC/GridUNESP) of São Paulo State University (UNESP), and the "Central de Equipamentos e Serviços Multiusuários (CESM-UNIFESP)" for technical support.

Conflicts of Interest: We wish to confirm that there are no known conflicts of interest associated with this publication and there has been no significant financial support for this work that could have influenced its outcome.

\section{References}

1. Lorenzi, F.J.A. Plantas Medicinais do Brasil: Nativas e Exóticas; Instituto Plantarum: Nova Odessa, Brazil, 2002.

2. Ferreira, Z.S.; Roque, N.F.; Gottlieb, O.R.; Oliveira, F.; Gottlieb, H. Structural clarification of germacranolides from Calea species. Phytochemistry 1980, 19, 1481-1484. [CrossRef]

3. Lima, T.C.; Souza, R.J.; Silva, F.A.; Biavatti, M.W. The genus Calea, L.: A review on traditional uses, phytochemistry, and biological activities. Phytochem. Res. 2018, 32, 769-795. [CrossRef]

4. Seaman, F.C. Sesquiterpene lactones as taxonomic characters in the Asteraceae. Bot. Rev. 1982, 42, 121-595. [CrossRef]

5. Padilla-Gonzalez, G.F.; Santos, F.A.; Da Costa, F.B. Sesquiterpene lactones: More than protective plant compounds with high toxicity. Crit. Rev. Plant Sci. 2016, 35, 18-37. [CrossRef]

6. Scotti, M.T.; Fernandes, M.B.; Ferreira, M.J.P.; Emerenciano, V.P. Quantitative structure-activity relationship of sesquiterpene lactones with cytotoxic activity. Bioorg. Med. Chem. 2007, 15, 2927-2934. [CrossRef]

7. Dewick, P.M. Medicinal Natural Products-A Biosynthetic Approach, 3rd ed.; John Wiley \& Sons, Ltd.: Nottingham, UK, 2009.

8. Bohlmann, F.; Jakupovic, J. Neue germacranolide aus Calea urticifolia. Phytochemistry 1979, 18, 119-123. [CrossRef]

9. Herz, W.; Kumar, N. Sesquiterpene lactones of Calea zacatechichi and C. urticifolia. Phytochemistry 1980, 19, 593-597. [CrossRef]

10. Ober, A.G.; Urbatsch, L.E.; Fischer, N.H. Sesquiterpene lactones from Calea leptocephala. Phytochemistry 1986, 25, 467-470. [CrossRef]

11. Yamada, M.; Matsuura, N.; Suzuki, H.; Kurosaka, C.; Hasegawa, N.; Ubukata, M.; Tanaka, T.; Iinuma, M. Germacranolides from Calea urticifolia. Phytochemistry 2014, 65, 3107-3111. [CrossRef] [PubMed]

12. Wu, H.; Fronczek, F.R.; Burandt, C.L.; Sjawiony, J.K. Antileishmanial germacranolides from Calea zacatechichi. Planta Med. 2011, 77, 749-753. [CrossRef] [PubMed]

13. Lee, I.Y.; Fronczek, F.R.; Malcolm, A.; Fischer, N.H.; Urbatsch, L.E. New germacranolides from Calea ternifolia and the molecular structure of $9 \alpha$-hydroxy-11,13-dihydro- $11 \alpha, 13$-epoxyatripliciolide- $8 \beta$ O-(2-methylacrylate). J. Nat. Prod. 1982, 45, 311-316. [CrossRef]

14. Batista, J.M.J.; Blanch, E.W.; Bolzani, V.S. Recent advances in the use of vibrational chiroptical spectroscopic methods for stereochemical characterization of natural products. Nat. Prod. Rep. 2015, 32, 1280-1302. [CrossRef] [PubMed]

15. Batista, A.N.L.; Santos, F.M.J.; Batista, J.M.J.; Cass, Q.B. Enantiomeric mixtures in natural product chemistry: Separation and absolute configuration assignment. Molecules 2018, 23, 492. [CrossRef] [PubMed]

16. Marchetti, G.M.; Silva, K.A.; Santos, A.N.; Souza, I.M.; Tinti, S.V.; Figueira, G.M.; Foglio, M.A.; Carvalho, J.E. The anticancer activity of dichloromethane crude extract obtained from Calea pinnatifida. J. Exp. Pharmacol. 2012, 4, 157-162. [CrossRef]

17. Nakagawa, Y.; Iinuma, M.; Matsuura, N.; Yi, K.; Naoi, M.; Nakayama, T.; Nozawa, Y.; Akao, Y. A potent apoptosis-inducing activity of a sesquiterpene lactone, arucanolide, in HL60 cells: A crucial role of apoptosis-inducing factor. J. Pharmacol. Sci. 2005, 97, 242-252. [CrossRef] 
18. Caldas, L.A.; Ionta, M.; Horvath, R.O.; Silva, G.A.F.; Ferreira, M.J.P.; Sartorelli, P. Calein C, a sesquiterpene lactone isolated from Calea pinnatifida (Asteraceae), inhibits mitotic progression and induces apoptosis in MCF-7 cells. Front. Pharmacol. 2018, 9, 1191. [CrossRef]

19. Matsuura, N.; Yamada, M.; Suzuki, H.; Hasegawa, N.; Kurosaka, C.; Ubukata, M.; Tanaka, T.; Iinuma, M. Inhibition of preadipocyte differentiation by germacranolides from Calea urticifolia in 3T3-L1 cells. Biosci. Biotechnol. Biochem. 2005, 69, 2470-2474. [CrossRef]

20. Rivero, A.; Quintana, J.; Eiroa, J.L.; López, M.; Triana, J.; Bermejo, J.; Estévez, F. Potent induction of apoptosis by germacranolide sesquiterpene lactones on human myeloid leukemia cells. Eur. J. Pharmacol. 2003, 482, 77-84. [CrossRef]

21. Ohguchi, K.; Ito, M.; Yokoyama, K.; Iinuma, M.; Itoh, T.; Nozawa, Y.; Akao, Y. Effects of sesquiterpene lactones on melanogenesis in mouse B16 melanoma cells. Biol. Pharm. Bull. 2009, 32, 308-310. [CrossRef]

22. Newman, D.J.; Cragg, G.M. Natural products as source of new drugs from 1981 to 2014. J. Nat. Prod. 2016, 79, 629-661. [CrossRef]

23. Allard, P.M.; Péresse, T.; Bisson, J.; Gindro, K.; Marcourt, L.; Pham, V.C.; Roussi, F.; Litaudon, M.; Wolfender, J.L. Integration of molecular networking and in-silico MS/MS fragmentation for natural products dereplication. Anal. Chem. 2016, 6, 3317-3323. [CrossRef] [PubMed]

24. Dasari, S.; Tchounwou, P.B. Cisplatin in cancer therapy: Molecular mechanisms of action. Eur. J. Pharmacol. 2014, 5, 364-378. [CrossRef]

25. World Health Organization (WHO). Global Cancer Observatory, 2019. Available online: https://gco.iarc.fr/ (accessed on 29 March 2020).

26. Park, J.W.; Choi, S.H.; Yoon, H.I.; Lee, J.; Kim, T.H.; Kim, J.W.; Lee, I.J. Treatment outcomes of radiotherapy for anaplastic thyroid cancer. Radiat. Oncol. J. 2018, 36, 103-113. [CrossRef] [PubMed]

27. Zimmerman, S.; Fouché, G.; Mieri, M.; Yoshimoto, Y.; Usuki, T.; Nthambeline, R.; Parkinson, C.J.; Van der Westhuyzen, C.; Kaiser, M.; Hamburger, M.; et al. Stucture-activity relantionship study of sesquiterpene lactones and their semi-synthetic amino derivatives as potential antitrypanosomal products. Molecules 2014, 19, 3523-3538. [CrossRef]

28. Schmidt, T.J.; Costa, F.B.; Lopes, N.P.; Kaiser, M.; Brun, R. In silico prediction and experimental evaluation of furanoheliangolide sesquiterpene lactones as potent agents against Trypanosoma brucei rhodesiense. Antimicrob. Agents Chemother. 2014, 58, 325-332. [CrossRef] [PubMed]

29. Caldas, L.A.; Yoshinaga, M.L.; Ferreira, M.J.P.; Lago, J.H.G.; Souza, A.B.; Laurenti, M.D.; Passero, L.F.D.; Sartorelli, P. Antileishmanial activity and ultrastructural changes of sesquiterpene lactones isolated from Calea pinnatifida (Asteraceae). Bioorg. Chem. 2019, 83, 348-353. [CrossRef]

30. Cabanillas, M.E.; Zafereo, M.; Gunn, G.B.; Ferrarotto, R. Anaplastic thyroid carcinoma: Treatment in the age of molecular targeted therapy. J. Oncol. Pract. 2016, 12, 511-518. [CrossRef]

31. Celano, M.; Maggisano, V.; Rose, R.F.; Bulotta, S.; Maiuolo, J.; Navarra, M.; Russo, D. Flavonoid fraction of Citrus reticulata juice reduces proliferation and migration of anaplastic thyroid carcinoma cells. Nutr. Cancer 2015, 67, 1183-1190. [CrossRef]

32. Allegri, L.; Rosignolo, F.; Mio, C.; Filetti, S.; Baldan, F.; Damante, G. Effects of nutraceuticals on anaplastic thyroid cancer cells. J. Cancer Res. Clin. Oncol. 2018, 144, 285-304. [CrossRef]

33. Frisch, M.J.; Trucks, G.W.; Schlegel, H.B.; Scuseria, G.E.; Robb, M.A.; Cheeseman, J.R.; Scalmani, G.; Barone, V.; Mennucci, B.; Petersson, G.A.; et al. Gaussian 09, Revision, A. 02; Gaussian, Inc.: Wallingford, UK, 2009.

Sample Availability: Samples of the compounds $\mathbf{1}$ and $\mathbf{2}$ are available from the authors. 